\title{
Constructal Law of Institutions within Social Organizations
}

\author{
Luciano Ondir Freire*, Delvonei Alves de Andrade \\ Instituto de Pesquisas Energéticas e Nucleares (IPEN-CNEN/SP), São Paulo, Brazil \\ Email: *luciano.ondir@gmail.com
}

How to cite this paper: Freire, L.O. and de Andrade, D.A. (2018) Constructal Law of Institutions within Social Organizations. Open Journal of Applied Sciences, 8, 103-125.

https://doi.org/10.4236/ojapps.2018.83009

Received: February 6, 2018

Accepted: March 17, 2018

Published: March 20, 2018

Copyright ( $) 2018$ by authors and Scientific Research Publishing Inc. This work is licensed under the Creative Commons Attribution International License (CC BY 4.0).

http://creativecommons.org/licenses/by/4.0/

(c) (i) Open Access

\begin{abstract}
This work looked for a unifying theory between physical-biological domain and social sciences. Constructal law unified physical and biological domain by telling the general sense in which flow systems tend to evolve. Management theory looks for relations between institutions and human agency. Although being state of mind entities, institutions follow constructal law. This work proposed the main organization flows are information and credit. Biologic instincts derived from Darwinian natural selection are the driving or blocking forces of such flows. Once biologic instincts systematically block information and credit flows in large numbers, this work proposed every human organization must have institutions to inhibit some behaviors. Those institutions need to be present, at least partially, in formal rules of social groups. This way it is possible to predict expansion or downfall of human groups using objective and quantifiable data. Therefore, further studies may employ classical history to confirm this theory. This work analyzed some case studies to show qualitatively the application of proposed theory. Concluding, this work gave physically-biologically grounded guidance for institutional changes.
\end{abstract}

\section{Keywords}

Institutional Theory, Institutional Entrepreneurship, Unifying Theory, Constructal Law, Management Theory, Social Systems

\section{Introduction}

In management, the prediction of the success or failure of an organization is still an open problem. Yet, it is a capital question in management in practical terms. In a broader sense, authors do not agree completely on the causes of downfall of societies.

Agency theory is quite old and its principles date back to Adam Smith [1]. Its 
central tenet is the separation of ownership from control drives managers to have divergent interest from shareholders. The three common solutions to the agency problem are: Board of directors independent from officers; distributing part of enterprise ownership to officers; market for corporate control. Reference [1] revises the current literature and found no clear relationship between those solutions and firm performance. Yet, it is clear the agency theory is consistent, empirical research could not give convincing evidence in its favor.

Currently, institutional theory describes the nature of institutions. Its central tenet is that isomorphism legitimates behavior [2]. However, institutions do change over time. Author of reference [3] proposed that there are change mechanisms, called institutional entrepreneurship. Authors of reference [4] propose a theoretical framework to explain transformations inside institutions despite the intrinsic institutional inertia. They describe mechanisms of how individuals come with innovative ideas, of how they find ways to try to implement their vision.

Authors of reference [5] analyze the difficulties new industries face in the absence of model institutions. They recognize the trust as a prime factor for success. In this work, the formal representation of trust is credit.

Reference [2] tells the central tenet of institutional theory is that isomorphism legitimates. They also found that each local community has cognitive, normative and regulative institutional forces which drive companies to contribute to charity in an equivalent way.

For institutional theory, individuals are embedded in the institutions. Institutions mold their values. The institutions tend to stability and to be isomorph. But contradictions between reality and values do occur. Values may become conflicting. Actors may have experience in other organizations which adopt different institutions. Entrepreneurs may seek self-interests or group interest. They may envisage changes and corresponding benefits from imagination. Of course, entrepreneurs may either improve institutions or degrade them.

Authors of reference [6] proposed that firms could be systems exchanging resources with surrounding actors. Firms would then have their behavior molded to assure critical resources, like capital, legitimacy, raw materials. Reference [7] gives a review on resource dependence literature. They found that there are five known processes firms achieve access to resources: Merges and acquisitions; joint ventures; board of directors; political action; executive succession. Empirical research showed a partial success of resource dependence theory [7].

It important to note that the access to resources may be the flows this system needs to survive. Legitimacy, as postulated by resource dependence literature, is analogous to credit in this work.

In physical and biological domain, reference [8] proposed the constructal law. The constructal law states that a flow system morphs in the sense it eases the flows it needs to survive and persist in time. This law allowed explaining many phenomena ranging from physical domain to biological domain [9]. 
People also organize cities to ease the flow. People and goods movement need access ways to ease transport. Bejan developed some relations between the access ways parameters, showing that human social systems also bow to constructal law [10].

An author that makes the analogy between a firm and a river basin is [11]. For him, the credit (in this case, money) flows up the hierarchy like the water flows from small rivers to large rivers. He also makes analogy of behavior of water/ credit at each stage or hierarchical level. At his firm, he created rules and a communication protocol between hierarchical levels to ease the credit flow.

Departing from institutional entrepreneurship model, this work relevance exists in the innovative proposition that institutions bow to constructal law, even institutions being state of mind entities. The main flows of an organization are credit and information. Of course, organizations engaged in production of goods also need physical assets. But the exchange of any physical material or good involves credit and information. Institutions evolving in the sense of improving those flows make organizations grow powerful. Institutional entrepreneurship in the sense of constraining credit and information flows withers an organization. A complete credit and information block definitively destroys any organization. Organizations, being flow systems, compete for resources and the more efficient institutions prevail, and less efficient institutions cease to exist. This way, this work shows an objective and quantifiable law to predict a generic organization future development, gave their physical flows do not suffer blockage.

Credit in the context of this work is an expectation, from the part of society, of future honorable deeds from a person or organization. Credit is formally and publicly defined by socially built symbols, or, in other words, society always institutes a set of credit symbols. Money, social status, titles, hierarchical positions and authority often display credit. In societies or social groups where realizations are a way to obtain credit, people see citations, capital and acknowledgement as symbols of credit.

Some may argue that credit is money, as in the common language. It is not completely true, because money is a tool created by government used to symbolize a particular type of credit, that is, the delivery of goods or services. Money does not obtain other forms of credit alone, like positions at some organizations or academic titles.

Other people may argue that credit is past realization, like it is in academic world, but it is not true in general, that is, people may choose to give titles, authority or money based on future expectations. Credit is the one of the main motivations for people to behave according to rules and to execute orders. Most people do not work nor follow orders without receiving credit. Credit symbols only have value inside a social group. For instance, people cannot use a copper coin from Roman Empire today to buy goods. Human instincts drive people to obtain credit as an end (need of acceptance and recognition) or as a tool to satisfy their physical needs (salary to buy food). 
Information in the context of this work is data exchanged between people to guide actions and decisions. For instance, orders and reports are types of information flown inside institutions. Information needs a common protocol between sender and receiver (language) and a physical media, like paper or internet. Information is essential to allow people to act so to some stated needs.

Realization in the context of this work is the production of goods and services, the production of information and production of any innovative ideas. Innovative ideas may be philosophical or mathematical works. People call production of goods and services "economic activity." Research and development is production of information. Realization is one of the main reasons people endure strife and keep efforts, as it is a way of self-expression and to get self-esteem, self-confidence and self-knowledge.

This work gives a tool to guide institutional entrepreneurship in the sense of improvement of organizations flows of information. It gives a physically grounded guidance for entrepreneurs seeking the best solution in a competitive world. This law allows predicting future developments of a given organization. This also creates ethical questioning about philosophical values, grounded on physical phenomenon. Last, but not least, it is useful to analyze historical events, increasing comprehension of rise and downfall of societies.

\section{Assumptions and Method}

This section presents underlying assumptions made for this work, followed by the method adopted. The first assumption is that living organisms' behavior mutate slowly over time. This means humankind instincts did not change significantly throughout history. The second assumption is that human brain derives from animal brain according Darwinian evolution. A consequence is that instincts are psychological drives useful in wild life. The third assumption is that institutions are artificial human creations that develop values and desires on individuals and suffer random changes by agency and institutional entrepreneurship. Therefore, institutions drive the behavior of super organisms (organizations) like genes drive individuals' behavior. Because institutions drive organizations behavior and suffer random changes, Darwinian evolution applies to institutions. The fourth assumption is that agency sources are instincts and institutions individuals bring from external organizations, while knowledge and creativity enable agency [4].

The core proposition is: credit and information are the main organization flows. Mechanisms (institutions) to ease them keep organizations alive. Consequently, institutions must prevent behavior (driven by instincts) blocking those flows. Behavior may block credit and information flows by institutional entrepreneurship (for instance, abolition of private property) or individual non-institutionalized actions (for instance, robbery, deception).

The first step is to analyze qualitatively a pipe element, finding its functions or requirements. After, analogies with organization flows (credit and information) 
are set up. In a second step, this work makes an investigation of some human instincts on grounds of Darwinian evolution. The main underlying assumption here is that every psychological drive needs to be useful to pass on the individual genes. Reference [12] adopted a similar approach to understand honeybees' behavior. After, this work discusses those instincts observable effects on human behavior. In a third step, this work shows typical solutions to prevent credit and information flows disruption. In a fourth step, this work presents some case studies. Although a quantitative analysis would be possible, for brevity, this work did a qualitative analysis of those systems to ease comprehension. This work adopted only well-known cases to ease comprehension and critics. This work shows both cases of improving flows and disrupted flows and added an insect social system to show the generality of this law. For the improved flows cases, this work chose the scientific community and for the flow disruption case, it chose the fall of Roman Empire. For the insects' case, this work chose the honey bee society.

\section{Development}

\subsection{Analogy of Organization Flows with Physical Flows}

The basic flow transmission element is the pipe. In the context of this work, pipe is not the human solution for fluid transport, but an abstraction of reality. It is a generic access way for a generic stream, be it fluid, heat or information. Its main function is to ease stream. As the best relation between perimeter and surface is the circle, this form is very common in nature.

It also need to prevent other types of material enter in the stream. It assures the needed free volume for the stream. Other types of material are contaminants and may plug the pipe. In some natural occurrences, a physical barrier performs this function, like in animal veins or air ways. In others, a conjunction of natural forces does this function, like in a river. In a river, the ground physical properties, allied to gravity, holds ground particles in place. Otherwise, water flow would carry away those ground particles and plug the river. In a flexible hose, the internal pressure plays this role, assuring the internal free volume.

The last function is to mitigate flow losses. If the pipe loses part of flow in the way, the destination starts to receive less stream, degrading the flow. If the destination does not receive the needed flow, it withers and may cease to exist. In animal body, an example is blood loss. Again, a physical entity or by a conjunction of natural forces may perform this function. In a flexible hose, the watertight material plays this hole. In electricity conduction, the absence of a conductive media prevents electrons from going out of the wire. Figure 1 presents a graphical representation of this abstraction of pipe element.

Mind flows, like credit and information, also need a proper space for transmission. Mental discipline developed by institutions (set of social rules within the organization) generates this space. Institution orients towards goals, which lead to realization in a broader sense. 


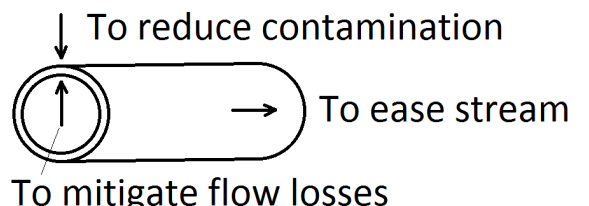

Figure 1. Pipe element functional analysis.

Interest rates and depreciation relate time and credit, so, people say time is money. Information needs a delay for production, transmission and understanding and that delay relates information to time. It sometimes takes many years to produce the detailed design of a complex system, like commercial plane or a nuclear submarine.

For practical reasons, realization of things needs information like plans, projects and orders as people need to know what clients expect to act correctly. Conversely, people may evaluate past realizations to bring more information about how to improve performances for the future. This experience feedback refines the competence of the people and institutions in charge of the realization.

Last, but not least, realization may bring credit such as titles, payments in money and public recognition. As everything has risks and uncertainties, people tend to trust more who has entitlements and proved competence to lead new realizations. Furthermore, it is always necessary to pay for raw materials, training and tools before realizing something. This way, one may say both that realization may bring credit and realization needs credit. When people pay for tools, training and raw materials, it is investment. Figure 2 summarizes the relations between information, credit, realization and time.

The two flows (information and credit) contribute to the realization inside organizations. It is important to note those flows relate to time. Making the analogy between the generic pipe elements, organizations need to create channels for those flows. These channels need to have the same functions as the generic pipe element.

For the information channel, it is important to reduce, as much as possible, the time to communicate and the energy spent at it. In written communication, this means to reduce time and brain effort to write and to understand a text. A solution is the use of simple and concise sentences. Authors should use only simple words to reduce the mean time of the reader to understand the text and reduce risk of misunderstanding. Documents should use figures and tables as much as possible. To prevent contamination of irrelevant or false data, the information channel should filter only the required data for realization. Other information, self-expression and unreliable data should be out of information channels. The reason is it may induce people to lose focus on important aspects. To mitigate flow losses, a solution is to impose protocols. Protocols need to be known by both sender and receiver. Protocols may help to keep data integrity, contributing to make the receiver get all information needed to act.

For the credit channel, it is important to ease the credit attribution. This 


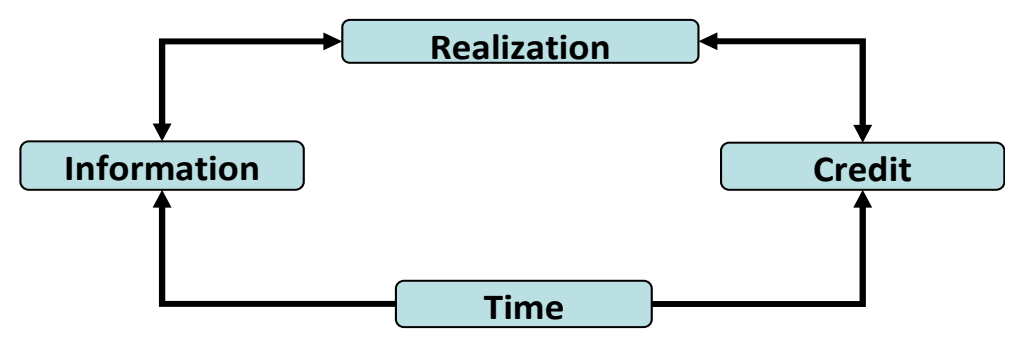

Figure 2. Relations between time, credit, information and realization within institutions.

happens because of the relation between credit and time, that is, interest rate. If an organization delays paying stakeholders, they are going to ask compensations. Organizations also need to reduce attribution of credit without a corresponding realization. If people attribute credit without solid evidence of its realism, there are frequent failures, like financial losses. Frequent failures lead to disbelief and pessimism, destroying the organization. On the other side, it is mandatory to assure people receive credit for their realization. If people are afraid of not receiving credit, they need compensations for the perceived risk. Table 1 shows the analogy between the pipe element functions with information and credit channels functions.

Table 2 shows the constructal law flows found for each domain, like physical domain, biological domain and social domain. Constructal law also applies to biology. Genes morph in the sense they ease their own flow into new generations, which is a new way of telling Darwinian evolution theory. It is a try to present a unified law about systems development.

\subsection{Animal Mind Instincts and Their Effects}

This chapter theorizes about animal brain drives due Darwinian evolution. $\mathrm{Hu}$ mans are social animals. Social animals with sophisticated brains (monkeys, elephants) tend to develop etiquette. Etiquette is a set of external manners and gestures, repeated like a ritual by individuals of the same group. Such gestures characterize the group and distinguish it from others from the same species. The advantage of such trait is to create social cohesion and to allow group learning, which is the retention of procedures that improve survival probability (or vital flows). This way, individuals have access to centuries of accumulated experience without the need of personal experience as imitation and enforcement transmits this knowledge. Enforcement means institutionalized punishment for dissonant behavior.

Moralism is the impetus of imitating the group etiquette and imposing it on others. Individuals with brains integrating strong moralism have superior survivability in harsh environments. The reason is that knowledge accumulates over time, allowing individuals profit of procedures whose reason they may not know. However, if established procedures become inadequate, this group may either perish of change its behavior. The reason is moralism drives individuals 
Table 1. Analogy of information and credit channels with pipe element.

\begin{tabular}{ccc}
\hline Pipe element & Information channel & Credit channel \\
\hline To ease stream & To ease communication & To ease credit attribution \\
To reduce contamination & To reduce false or irrelevant data & To reduce unreal credit \\
To mitigate flow losses & To mitigate loss of data & To reduce credit loss \\
\hline
\end{tabular}

Table 2. Constructal law applied to different domains.

\begin{tabular}{cc}
\hline Domain & Flows \\
\hline Physical & Mechanical stress, fluids, heat, electricity \\
Biological & Genes, food, displacement \\
Social & Credit and information \\
\hline
\end{tabular}

into acceptance of procedures without questioning. Another problem is that distinct groups tend to fight each other once they feel hostility against people using different procedures. Moralism also gives origin to collective rituals because they create a sensation of belonging to the group and security.

Moralism is the foundation of institutions uniformity, or isomorphism. It allows repeatability on processes because people tend to keep procedures. It is the main driver behind the facts seen in institutional theory. It has the inconvenient of making individuals hostile to external public. This hostility may drive individuals into negating information or credit. Even physical aggressions may happen under different pretexts.

An instinct derived from moralism is jealousy. It is the desire of obtaining what others have, not because it is pleasant, but just by an imitation-like instinct. For instance, monkeys get agitated if other monkey receives a different fruit as reward. This instinct drives the entire group in a single direction, keeping the group integrity. It is enough a leader (the first to act, not boss) adopts a new successful procedure and others will follow. Jealous people tend to have superior survivability because they exert themselves more often and tend to produce more.

A part of moralism is vanity. Vanity is the desire of individual of having a positive reputation in the group. This drives people spontaneously into conformity. Vanity drives people into lying to keep in conformity. Studies show that a person may believe that the group is wrong, but few have courage to disagree and risk its reputation. This means production of false information or suppression of valuable information. Another matter is people avoid staying in a social group that does not approve them, or so they believe. The simple absence of compliments may cause credit loss. And adulators tend to receive unreal credit from people.

One derivation of moralism is dominance. It is the wish to control others behavior. Different from moralism, it drives individuals not into adoption of group 
etiquette, but into creation of a new etiquette, coming from imagination and scheming. The dominant individual tries to impose behaviors different from he/ she adopts. This individual gives orders inconsistent with its own behavior (do what I tell, not what I do). Dominance helps individuals to manipulate others into giving abundant resources. The solution to do this is by development of charisma. Charisma is a set of behavior that seduces people and allows the charismatic (dominant) individual obtain favors and credit from others. Charisma typically uses vanity of others. This eases procreation (access to more sexual partners) and survival (protection, access to food) of the dominant individual.

However, dominance has the effect of driving individuals into elimination of rivals. If physical means of eliminating the rival (killing, shunning) are not available, it drives people into defamation campaigns. This means introduction of false information in the communication channels within the group. The goal is to discredit the opponent, which means a problem of credit loss.

Complementary to dominance there is subservience. Subservience is the drive to obey and imitate beautiful, healthy, big, fit and well-dressed individuals, causing the dictatorship of beauty. In nature such drive prevents disputes for dominant positions and it has the advantage of profiting of successful procedures. Those procedures are successful because they turned the individual that adopted it into a beautiful one. For instance, a given person starts eating a certain proportion of different food. After some time, this person becomes more beautiful than the rest which eats the traditional food. Subservient individuals instinctively start to imitate this person and they become healthier than the non-subservient individuals. This instinct is the basis for the advertising with beautiful, tall, fit and healthy people. Marketing professionals know that the image of a beautiful person using a given product attracts customers. This means people tend to give credit to beautiful people regardless their deeds. While it is useful for imitating the food habits, in a broader sense it creates problems of unrealistic credit attribution.

Attachment is the wish of people of staying near individuals they passed a long time together. It is interesting to keep the group integrity and loyalty. It gives mutual help and protects individual life. The problem is that, coupled with moralism, people tend not giving credit outside their social group. Another problem is that people may revolt if their contract with the organization ends. The sole probability of the firm obliging people to leave makes them uneasy and rebellious. Attachment makes people ask for very high salaries to compensate for this psychological pain. Attachment is a biological drive, so even if a person believes in freedom and short contracts, there is anger when the institution ends the contract.

Filial piety is the biological drive of protecting individuals in the same bloodline. This is observable in many mammals, like monkeys and lions. This is fundamental to allow genetic propagation. Knowing that parents and sons protect themselves, it generates an automatic credit attribution, but it may be a problem 
of unreal credit attribution. In fact, hereditary power transmission is universal. And this generates succession crisis that often destroys firms or even societies.

Rebellion is the biological drive to kill the alpha male and replace him. It is hostility against powerful entities. The powerful entity may be the group, the establishment, a powerful institution or a strong male. This drive individuals into development of brute force in nature. In society, it may lead to development of competences as a substitute of brute force. It is an individual drive, which forces the individual to want to be strong, independently from other people. It is important to have access to sexual partners and pass on his genes. It is primarily for males. It is the main drive behind science. This drive individuals into non-conformity or innovation. This instinct makes exciting the histories of individuals successfully challenging powerful organizations or giants. Examples are Tristan against giant Morholt, Silvius Brabus against Druon Antigoon, Galileo against Catholic Church and Myamoto Musahi against Yoshioka academy. Rebellion drives people into personal discovery and innovation, but not into divulgation of information or learning from other people, potentially breaking information flow. Also, it creates distrust, negating credit just because a given institution is big. People also tend to give credit to individuals (heroes like Myamoto Musahi or Cú Chulainn) due violent actions and not constructive behavior.

Presumption is the desire of becoming superior. It drives individuals into realization and competitive attitude. Different from rebellion, it drives people into sportive competition without killing the rivals. The rivals become tools for self-development. This instinct is interesting because it drives individuals into training and overcoming limits. Well trained individuals get better chances of survival and procreation than lazy individuals. This is the drive behind sports and games and justifies the excellence concept which is interesting for organizations to cultivate. It may generate lack of interest in communication, however.

Sexual attraction is the drive to have sex with healthy and young partners. It has basic role in procreation and allowing gene propagation. Individuals with low sexual desire tend to die without leaving children. The problem is that the intense pleasure drives individuals into trusting in sexual partners. This may cause unreal credit attribution. Many kings had problems for trusting too much in lovers. Also, sex refusal may cause credit loss.

Greed is the desire of obtaining resources that the individual does not need in the moment. It is interesting from a Darwinian point of view because it leads to accumulation of resources which may be useful in future. However, it may drive people into conflicts, breaking both information and credit flows. Greedy people do not want to share anything, information included. They want to get resources out of view of the group. They tend to negate credit or reduce credit given to others. They have the temptation to rob resources from others. Yet, greed is one of the main drives of social development.

The most dangerous instinct for institutions is indifference or apathy. It is a capability of blocking a desire after being convinced it is not possible or it has 
unacceptable consequences. It is the capability that allows people not committing crimes. It may become powerful enough to block every drive if institutions train people into it. However, if people develop apathy towards credit, realization or information, they become inutile for organizations. This way, former slaves may not integrate into capitalist organizations. Apathy is also of great interest for institutions. Once institutions definitively prevent a behavior, people learn how to channel out the desires leading to that behavior.

Concluding this part, institutions must develop the instinctive drives in people. Ill directed apathy may mean organizational death and institutions need also to channel drives to prevent disruption of credit or information flows. If people see personal advantage in disrupting information and credit flows, it is sure a part of them is going to do so. In the big numbers, in absence of institutions blocking self-rewarding behaviors, it is sure there will be enough people to block credit or information flows within an organization. But if there are methods, supernatural beliefs or punishments preventing credit and information disruption, people keep working together. If people cooperate, they can transform the world according with their desires.

\subsection{Solutions to Counter Natural Flow Blocking}

Societies created many solutions to allow credit and information flows. Before development of science, many of those solutions were based on supernatural statements. One of them is the divine punishment concept. The divine punishment implies the existence of a supernatural entity, God, which is seeing people actions all the time. This God takes notes, and, upon death of everyone, He passes judgments according deeds. Ancient Egypt explored this concept, described in the Egyptian book of the dead. This idea prevented Egyptian people from killing, adultery, lies, and other deeds that would cause suffering on others.

But supernatural beliefs never worked alone. The concept of transparency always is present. Transparency is the right of doubting without proof. Transparency obliges the claimer or accuser to give proof and show to unrelated people the correctness of information he/she provides. Other solution is the adoption of methods or rituals to take major decisions. Those rituals were formal meetings where every person had opportunity to talk before the decision. This way, making intrigues was very difficult. Eventual liars were severely punished. This was the precursor of redundant supervision. Another concept is the relevance filtering, which let enter in channel only information which may bring profit.

Accountability typically reduces the loss of data in communication. The sender is usually responsible for assuring the receiver understood the message. Protocols with checks also help to keep information integrity. Channel redundancy, segregation and independence are other solutions.

To ease communication and to reduce data loss, many societies created written language. Technological development brought better materials and better written languages. Nowadays, digital technology allows so huge information flows that the limit is in human brain. 
The creation of symbols by authorities helps credit attribution. The media for those symbols also evolved throughout time, from metal coins to paper coin, and from paper to electronic coin. Academic titles also profited from faster communication media. Procedures also evolved to become faster.

Faster procedures and better media also eased the possibilities of falsification and speculative bubbles in prices. Governments adopted taxes over transactions to damp speculative bubbles. To regulate the monetary value, societies created monetary authorities to prevent excessive emission of money in the market, what would cause inflation. Another solution is to give credit only after the demonstration of realization or to set penalties in case of noncompliance with earlier promises. Methods also evolved to include redundant and independent supervision, improving the quality of works.

To assure people their work is going to receive recognition, institutions usually enforced some principles. One of them is the private property principle. By this principle, every person has the right to keep wealth and rightful belongings. The use of written contracts allows setting up objectively what rightful belongings are. This way, after performing a task or selling something, state laws oblige the other part to follow the contract. Of course, to assure private property, state must monopolize use of violence, so people engage only in voluntary transactions. It is implicit that state limits actors in their spectrum of decision, excluding violence. The state also makes available courts where authorities solve issues between people according with public laws. The state courts work as redundant and independent supervision. Last, but not least, an important solution is to enforce standard rituals across the organization. The cause is people are hostile to alien etiquette and do not trust individuals with strange manners. Rituals enforcement places everybody in the same family, from an instinctive point of view, improving mutual trust and easing credit attribution.

Table 3 presents the summary of solutions typically adopted by societies throughout history.

Table 3. Solutions to assure credit and information flows.

\begin{tabular}{|c|c|}
\hline Function & Solutions \\
\hline To ease communication & Inventions of media, simplicity \\
\hline To reduce false or irrelevant data & $\begin{array}{l}\text { Punishment for lying, free speech, right to contradictory, } \\
\text { transparency, divine punishment beliefs, redundant } \\
\text { supervision, relevance filtering }\end{array}$ \\
\hline To mitigate loss of data & $\begin{array}{l}\text { Responsibilities, protocols, inventions of media, channel } \\
\text { redundancy, segregation and independence }\end{array}$ \\
\hline To ease credit attribution & Inventions of media, credit symbols, procedures \\
\hline $\begin{array}{l}\text { To reduce unreal credit } \\
\text { attribution }\end{array}$ & $\begin{array}{l}\text { Taxes, monetary authorities, credit subjected to earlier } \\
\text { realization, penalties for broken promises, redundant } \\
\text { and independent evaluation }\end{array}$ \\
\hline To reduce credit loss & $\begin{array}{c}\text { Private property principle, written contracts, state violence } \\
\text { monopoly, divine punishment beliefs, decision maker } \\
\text { limitation, redundant supervision by courts, universality, } \\
\text { enforcement of rituals }\end{array}$ \\
\hline
\end{tabular}


Concluding, it is interesting to note that solutions to keep flow integrity and prevent contamination also have flow constraining effects, both in physical flow and mind flows. In physical flows, the shear force causes pressures losses in a pipe, needing energy to drive fluids. In mind flows, the verification needs more work and delays to convey the credit or information. In both cases, energy is involved. The difference is mind flows need brain energy and more time. So, the goal is to minimize required brain energy from involved people. If people keep constant the available brain power, this means reducing time to do a task.

\section{Results}

This chapter presents some case studies to illustrate the constructal law concept applied to institutional analysis.

\subsection{Scientific Community Analysis}

Scientific community evolved since Greek philosophers down present day. It kept some elements from Aristotle and included other elements from other philosophers down to present day. This work focuses current scientific method. Science is singular because it restricts itself to mind entities, as it produces nothing but ideas or information. It is a perfect example of credit and information flow.

Scientific method holds the need to ease communication as a primary value. Since Aristotle, scientists adopted written word. Scientific community embraced the most modern communication media as soon as possible, like internet. It keeps knowledge open. It also evolves fast, creating better ways to present academic works, like audio slides. Most scientists, like Isaac Newton adopted simple and easy to understand language. Scientists used short and concise sentences, spontaneously adopting a single language. So, it considered clear the commitment to ease communication.

Scientific community is also strongly committed to reduce false or irrelevant data in the communication channels. A set of solutions realizes this function. The first is the way to present scientific work, which needs to be concise, focused in the activity developed. The author needs to make clear the relevance of the work. Less relevant discoveries receive lower priority (relevance filter). The method section needs to present how the researcher conducted the activities. The method section allows other scientists verify the results. This is a transparency solution. Another tool to reduce false data is the peer review. This reduces false claims or mistakes because the peer review can detect faults in procedure and prevent false data publication. In other words, the peer review is a redundant and independent supervision. Scientific also adopts severe punishments for authors which falsify data. Scientists have free speech if they can prove what they say. Every scientist has the right to disagree from other colleague. So, if an author publishes false data, others repeat the experiment, and nobody can prevent them of denouncing the falsification. In this case, typically researchers lose their 
titles and places at universities.

Scientific community also makes efforts to prevent data loss adopting written word since Aristotle. Now scientists start to publish articles along experimental data as separate annexes. Researchers usually follow a structure of work in articles which is a protocol. Ideally, scientists give all information needed to repeat the experiments or make a theorem demonstration and peer review checks this aspect.

Scientific community also recognizes as soon as possible relevant works and citations counting is a way to do this. Modern tools verify automatically how many citations a given work has received. Scientists created measures of number of citations. It is enough to present a valid work (thesis) and the researcher receives the title at once. In terms of citations, the time needed (to repeat experiments and publish new works) is the only limitation to the recognition.

On the other hand, the credit attribution is rigorous and limited to facts. Scientists give no credit without an earlier contribution and independent evaluators checks every contribution. Every researcher must recognize and cite earlier works. Promises of future work give no right to credit within science.

Credit loss is also a serious matter. Plagiarism interdiction is a core scientific value. Scientific community forbid authors from claiming to themselves a discovery from another researcher. There are multiple channels to divulgate a discovery. That means no individual has the possibility to prevent somebody of divulgating an idea. This means science limits every researcher in decision options. In case of important decisions, like in a thesis defense, multiple people, ideally unrelated, vote in a public and open event. A single person may denounce a fault, but only a committee can carry out the condemnation. Table 4 presents the summary about science solution to improve credit and information flows.

According with the proposed constructal law of institutions, the conformity of science with such functional requirements explains the expansion of scientific community and its impact on human society. Recent improvements on these functions show that scientific community is in expansion. It should saturate by

Table 4. Science solutions to assure credit and information flows.

\begin{tabular}{|c|c|}
\hline Function & Solutions adopted in scientific community \\
\hline To ease communication & Use of best media available, simplicity \\
\hline To reduce false or irrelevant data & $\begin{array}{l}\text { Punishment for false data, free speech, right to contradictory, } \\
\text { transparency, redundant supervision, relevance filtering }\end{array}$ \\
\hline To mitigate loss of data & Responsibilities, protocols, use of best media available \\
\hline To ease credit attribution & $\begin{array}{l}\text { Definition of metrics, automation of citation count, } \\
\text { recognition is immediate after verification }\end{array}$ \\
\hline To reduce unreal credit attribution & $\begin{array}{l}\text { Credit subjected to earlier realization, redundant } \\
\text { and independent evaluation }\end{array}$ \\
\hline To reduce credit loss & $\begin{array}{c}\text { Plagiarism interdiction, decision maker limitation, } \\
\text { redundant supervision }\end{array}$ \\
\hline
\end{tabular}


the size of the world which is not infinite, by ability of the world of paying researchers salary and projects and by the number of people wanting to make part of it.

\subsection{Honey Bee Analysis}

Bees are different from human beings. Many of the human instincts are not applicable to bees. However, making some analogies, this work shows that the mind flows are present within bee colony. Adopting bees as a use case is also important to show the generality of constructal law for institutions. For bees, the odors have analog role as a credit system for human. Bees use odors to recognize colony members and allow them access to hive. Odors are also important to show queen performance. Pheromones also regulate work distribution within colonies [13]. Bees also have credit in the sense they believe or not in what others tell.

Dances do the communication in beehive, as bees communicate the distance and direction of sources of food or new homes [14] [15].

To ease communication, bees adopt simple language and odor signals. The message transmission does not take long. In fact, hives adapt their work very fast according to weather and other conditions. The place where dances occur inside the hive is also best to ease the information flow (at the hive entrance) [12].

Collective mistakes can be fatal for a colony. So, when a scout reports a finding, a limited number of other bees go check the information. This is analog of redundant supervision and transparency in human society. Many scouts may give different information at the same time. This seems human free speech. However, bees judge from excitement of the scout how good is the new finding. They also seem to be able to judge with some information seems incredible. In some experiment, bees refused to follow scouts to a sugar water in the middle of a lake, placed there by the researcher [16]. Last, but not least, bees report only high profitable nectar sources [12], which seems a relevance filter.

To mitigate data loss, bees adopt redundant information channels. One channel is the odors. Other channel is dances, which give directions in relation to sun. There is more than one type of dances, like waggle dance and tremble dance.

The credit system, based in odors, is quite simple and robust. It allows prompt recognition of the kin members. Bees also give credit to information coming from scouts and search for the high profitability sources reported.

No individual has the possibility of taking decisions by the hive, characterizing a credit limitation. For instance, when the swarm needs to find a new home, scouts report sites. Those sites are cross-checked by others. Progressively, the number of bees visiting the best site grows up to the moment the colony decides to move in [15]. That means bees give immediate credit to information coming from scouts, but only choose a site after visiting personally some options. Reference [13] also showed that pheromones (transmitted by mouth to mouth feed- 
ing) regulates the work distribution. Older bees working outside feed mouth to mouth younger bees which work inside colony. This transmits a pheromone that prevents younger bees of becoming an external worker. If the proportion of external worker drops due natural death, younger bees become external workers. Therefore, if there is a high mortality of external workers, the colony reacts fast, keeping adequate work flow. So, pheromones (a part of their credit system) is closely related with production. The evaluation of performance affects also queens. If they do not perform well, the workers prepare a successor, in a process called queen supersedure [17]. Again, the individual receives credit only for its production.

The credit loss is very limited once odors are very robust. Their genes do not drive them into conflict, so the conflict level between individuals is very low [12]. It is a parallel of etiquette effect in higher primates. Another parallel is the policy of elimination of eggs not laid by the queen. All bees may potentially lay drone eggs, but very few do so. Only the queen may lay female eggs, which may be another queen or worker. Such rule (queen procreation monopoly) has a parallel in human state monopoly. The queen role is quite limited. The decisionmaking process is such that a single individual cannot introduce significant bias. Therefore, bees process and check any information. Another interesting aspect is that every worker receives credit from others. This means a certain universality of rules inside the colony.

Table 5 shows honeybee solutions to assure credit and information flows.

\subsection{Roman Empire Downfall Analysis}

The Roman Empire fall is a very complex subject. There are controversies about its causes and even if it was fall or a complex cultural transformation. Beyond interpretations, there are objective facts which anyone may obtain from primary sources. Theoretically, if any organization needs credit and information flows to survive, their disruption means organization decline and death. Knowing that

Table 5. Honeybee solutions to assure credit and information flows.

\begin{tabular}{|c|c|}
\hline Function & Solutions adopted in beehive \\
\hline To ease communication & Dance simplicity, use of odors, location for dances at entrance \\
\hline To reduce false or irrelevant data & $\begin{array}{c}\text { Free speech, transparency, redundant supervision, } \\
\text { relevance filtering }\end{array}$ \\
\hline To mitigate loss of data & Dance protocols, redundancy of channels (dances and odors) \\
\hline To ease credit attribution & Recognition of odors is immediate \\
\hline $\begin{array}{l}\text { To reduce unreal credit } \\
\text { attribution }\end{array}$ & $\begin{array}{c}\text { Production of pheromones guide behavior in closed loop with } \\
\text { production, queen supersedure, decisions subjected to evaluation } \\
\text { of colony members }\end{array}$ \\
\hline To reduce credit loss & $\begin{array}{c}\text { Odors are robust identification method, low conflict level, workers } \\
\text { eggs destruction, decision maker limitation, redundant } \\
\text { supervision, universality }\end{array}$ \\
\hline
\end{tabular}


roman institutions degraded at that time, their information and credit flows should have suffered disruption or at least, reduction.

First, one need to analyze the ease to communicate within roman state. Under Diocletian, the flow of direct requests to the emperor rapidly reduced and soon ceased altogether. No other form of direct access replaced them, and the emperor received only information filtered through his courtiers. Another issue was the obscurity of many and contradictory laws. The judicial proceedings had, in opinion people at that time, tedious and expensive forms. The judicial language was different from used language. Those elements give an idea that communication should be difficult in late Roman Empire.

Next, it is important to see how good the late Roman Empire was at reducing false or irrelevant data. For instance, when Alaric tried to negotiate with Honorius, but the messenger inflated his demands and Honorius responded with insults, which the messenger reported verbatim to Alaric. Another example was Constantius's habit of granting to his immediate entourage the estates of persons condemned of capital charges. Those close to the emperor gained a strong incentive to stimulate his suspicion of plots. In a general manner, in the late Roman Empire, use of proper judgments with right to defense declined. People started to seek their goals by intrigues and assassination. This introduced lies as people next to those in power saw profitable opportunities in doing so.

Roman authorities seemed also little worried about loss of data. They trusted completely on court members. Unlike republican periods, when institution enforced independent supervision, the late Roman Empire did not care much about it.

The material fact is that use of currency reduced in late Roman Empire. One scholar identifies a great increase in the purchasing power of gold, two and a half fold from 274 to the later fourth century, which may be an index of growing economic inequality between a gold-rich elite and a cash-poor peasantry [18].

Unrealistic credit also became the norm. The emperor, before the first among equals, became god-like. Emperors from Aurelian (reigned 270 - 275) onwards openly styled themselves as "dominus et deus" (lord and god), titles right for a master-slave relationship. The richest senatorial families were immune from most taxation and engrossed increasingly of the available wealth and income. Those families also became divorced from any tradition of military excellence. They had money not because they produced goods, but because laws assured their position. From the foundation of Rome till the reign of the Emperor Gratian, the infantry wore cuirasses and helmets. But negligence having introduced relaxation of discipline, the soldiers seldom put it on. Therefore, the soldiers, yet having military titles, were neither trained nor able to enter combat.

Finally, and the clearest was the incapability of Roman Empire of reducing the credit loss. Corruption, in this context the diversion of public finance from the needs of the army, may have contributed to the Fall. The rich senatorial aristocrats in Rome itself became increasingly influential during the fifth century; they supported armed strength in theory but did not wish to pay for it or to offer 
their own workers as army recruits. The army lost its credit source. Repeated attempts to economize on military expenditure included billeting troops in cities, where they could less easily exert military discipline and could more easily extort from civilians. Official cruelty, supporting extortion and corruption, may also have become more commonplace. People started to lose their wealth by lack of state violence monopoly. For the poor, the weight of taxes made still more oppressive by the intricate or arbitrary modes of collection. The taxes for the poor (the rich had less taxes) caused credit loss and impoverishment. The justice was partial. Contemporary people perceived universal corruption. Corruption increased the influence of the rich and aggravated the misfortunes of the poor. The riches have turned the public exactions to the increase of their private fortunes. They made the tax indictions their opportunity for plunder. It caused credit loss of the legal system at the eyes of the poor. The establishment of Christian orthodoxy led to official and private action against pagans and non-orthodox Christians. Christianity became the religion of any ambitious civil official. This led to loss of credit to pagans and non-orthodox Christians families, breaking the universality principle. Under Constantine the cities lost their revenue from local taxes, and under Constantius II (r. 337-361) their endowments of property. At a local level, from the early fourth century, the town councils lost their property and their power, which often became concentrated in the hands of a few local despots beyond the reach of the law. Therefore, decision makers became less limited. Within the late Roman military, many recruits and even officers had barbarian origins. There are records of soldiers using possibly-barbarian rituals such as elevating a claimant on shields. This means a breach in collective rituals enforcement and may have led to distrust and credit losses. Altogether, those credit losses led poor people into bagaudae. Official Imperial viewpoint told they were bands of brigands who roamed the countryside looting and pillaging. Reference [19] interprets the most completely assembled documentation about bagaudae, finding them as impoverished local free peasants, reinforced by brigands, runaway slaves and deserters from the legions. This population was trying to resist the labor exploitation and military systems, and all manner of punitive laws and levies. This way, the Empire lost more of its credibility as it could not protect citizens. This led to further impoverishment and stop of trade. Table 6 shows the summary of facts about credit and information flow in Roman Empire.

Concluding, there is evidence that those social changes were avoidable. It seems the state of mind of people of that time caused the changes. By simple attitude changes, individuals or social groups could have changed history. One example is Julianus (r. 360-363), who launched a drive against official corruption. This allowed reduction of the tax demands in Gaul to one-third of their earlier amount while meeting all government requirements.

\section{Discussion}

The first part is to discuss the underlying assumptions. The first assumption was 
Table 6. Roman Empire facts about credit and information flows.

\begin{tabular}{|c|c|}
\hline Function & Facts \\
\hline To ease communication & $\begin{array}{l}\text { Sophisticated language for state communication, complicated laws, } \\
\text { expensive judicial forms }\end{array}$ \\
\hline $\begin{array}{l}\text { To reduce false or irrelevant } \\
\text { data }\end{array}$ & $\begin{array}{l}\text { Speculation about loyalty led to death, use of divination practices, } \\
\text { intrigues reward court members }\end{array}$ \\
\hline To mitigate loss of data & $\begin{array}{l}\text { Actions without confirmation have taken place, absence of } \\
\text { independent supervision }\end{array}$ \\
\hline To ease credit attribution & Money had its use reduced, it became difficult to get titles \\
\hline $\begin{array}{l}\text { To reduce unreal credit } \\
\text { attribution }\end{array}$ & $\begin{array}{l}\text { Right to vote needed nothing from Rome citizens, politicians earned } \\
\text { places due spectacles, emperors imposed divine status, laws assured } \\
\text { wealth for rich families, soldiers did not train }\end{array}$ \\
\hline To reduce credit loss & $\begin{array}{l}\text { Poor needed to pay heavy taxes, slavery deprived people from credit, } \\
\text { barbarians had title negated on ethnic grounds, bagaudae }\end{array}$ \\
\hline
\end{tabular}

that living organisms' behavior mutate slowly over time and humankind instincts did not change significantly throughout history. Such assumption is the current scientific baseline as Homo Sapiens appeared about 200 thousand years ago and history started about 5 thousand years ago [20]. Furthermore, physical characteristics are very similar, which may allow us to assume a general similarity in mind aspects too. However, it is possible that executions and other forms of social punishment created an artificial selection, changing human mind faster than natural selection.

The second assumption is that human brain derives from animal brain per Darwinian evolution and instincts are psychological drives useful in wild life. Such assumption is in line with a proven theory and this work takes it as quite robust.

The third assumption is that institutions are like genes (mold organization behavior and change slowly over time). Such assumption is the basis of institutional theory and entrepreneurship theory [2] [3] [4] and it seems quite robust given the depth many have explored such theories.

The fourth assumption is agency sources are instincts and institutions individuals bring from external organizations, while knowledge and creativity enables agency [4]. Although this assumption may not be so robust as the others, it seems quite reasonable. If this assumption is incomplete (of even false) it does not invalidate this work, but part of analysis in Section 3.2.

It is important to note that there are imprecisions in official history, despite an analysis may assess some objective facts. There are also moral unwritten rules that may act as noise. For instance, if people believe it is mandatory to believe blindly in family and friends, transparency becomes a taboo. Superstitions may also weight in decisions and history may not record them officially. Therefore, just by looking for written customs and laws may be incomplete.

However, in analysis of a huge organizations, big numbers may compensate all those problems and primary sources should give an enough right view. The 
constructal law of institutions is generic and applicable to non-human social systems. The beehive case study gives a partial demonstration of that. This generality is due the basis on physics, giving a bridge between social domains (human and insect).

This work considers biology concepts, like Darwinian evolution, into understanding of agents' instincts. Constructal law also applies to biology as genes morph in the sense they ease their own flow into new generations, which is a new way of telling Darwinian evolution theory. In an analogous way, institutions morph in the sense to ease their own flow into a new generation of organizations. If physics are the similar throughout the universe, this law may also apply to extraterrestrial intelligent societies.

Information and credit flows are entwined, although distinct entities. If information is noisy, credit attribution surely suffers injustice problems. Complementing current institutional theory and institutional entrepreneurship theory, this law allows developing management theory grounded in physics and biology. This law may be applicable either for analysis of events like past societies ascension or downfall or for institutional entrepreneurship guidance.

This law allows prediction of future events. For instance, in an organization which gives emphasis on scientific formation for its top members, scientific information flows easily while filtering unproven ideas. This theoretically opens path for good decision making because decision makers working with scientific information and methods usually maximize realization. This means the size of the surrounding economy and natural resources will limit the organization growth, entering in steady state equilibrium following an S-shaped curve. On the other hand, organizations relying in pseudo-science or religious beliefs block information flow and their decisions are bound to fantasy. Whenever decision making decouples from reality, results surely also decouple from expectations, leading the organization to loss of credit flows and consequent death.

The constructal law of institutions allows prediction of ascension or decline of societies. Improved (credit and information) flows tend to improve economical production. Improved economical production is better quality and lower price products along better stakeholder satisfaction. Stakeholder satisfaction needs higher prices paid to commodities suppliers. From analogy with constructal law, a more efficient flow system displaces other less efficient competing flow systems. This means less efficient countries may lose their industry and become suppliers of commodities. This transient may be dramatic, especially for countries with majority of urban population. Political instabilities and wars may happen during that transition as large masses of population do not know how to survive.

This law accounts only mind aspects. Prediction is obviously prone to failures because it is impossible to know all variables, war effects, climatic changes effects, natural cataclysms. So regardless of those flows, they are not able to explain everything about the future of an organization. A complete analysis also 
need to consider the flow of physical resources in a constructal law fashion.

The constructal law of institutions also shows that we can know only part of the problem. This explains why works on resource dependence theory have only partial confirmation. A given enterprise may be very competitive, practical and efficient, but if the government outlaws its activities, it will cease to exist.

This work also gives insight into the lack of empirical evidence of agency theory. This work also confirms the central tenet of agency theory, once the human instincts generate necessarily diverging interests. However, barriers against mischiefs do not improve performance, but add overhead and cause efficiency loss. For instance, adding independent directors may drive officers into fame building activities outside the firm, instead of seeking competence development for the firm interests.

The advantage is the independent directors reduce frequency of development of inadequate behavior. For a fluidic analogy, a pipe with thicker walls does not perform better than pipes with thin walls in terms of charge losses. But pipes with thicker walls experience fewer ruptures. An avenue for future research of agency theory would be then to compare revenue stability of firms with their practices.

This work rejects fatalist views that individuals cannot change institutions of their time. People did not do so because they ignored the constructal law of institutions. There is an evidence for that in history. In ancient China, there was an empire which fell, dividing in some kingdoms. Its case was similar with Roman Empire which divided in two. Scholars calls this period the "warring states." An institutional entrepreneur called Shang Yang was able to convince a provincial leader to adopt some reforms. Those reforms were successful and, in the delay of one year, that province became rich. Soon it imposed a major defeat to one main kingdom. Few generations after, that province reached empire reunification. As it gave better life to people, emigration to Chin weakened neighbor countries [21].

An analysis may understand as flow improvements. He described a society in a state very similar to the late Roman Empire. He advocated simple and understandable laws, known by everybody. Shang Yang reforms ended rewards for unproven ideas, instated punishment for connivance with crimes and enforced redundant and independent supervision. He created a credit system based on titles that were at once attributed upon objective criteria. Food production or military victory decided attribution of political roles and titles. Every person had to obey the law, the king included, and the role of the king was very limited [21].

\section{Conclusions}

Constructal law seems to adhere to institutions inside organizations as genes inside organisms. The presence of institutions to protect information and credit flow allows predicting social groups' expansion or decline. This work showed a link between physical, biological and social fields. This work gave a fully objec- 
tive and quantifiable model of institutions within organizations and data for work is present in official history.

This work ideas may assess institutions in terms of the quality of solutions for functions of credit and information assurance. In management people need to think how to mitigate the risk (frequency and severity) of flow interruption events due to each one of the failure modes (in case of human beings, each one of psychological drives).

This means detection and correction. Detection needs redundant, segregated and independent information chains. Correction needs clear individual responsibilities and punishments. There is unavoidable risk concentration on top decision level. One solution is to improve monitoring and enforce more severe punishments for leaders.

Equality between stakeholders instead of dominant positions may ease information flow. Dominant stakeholders may not allow development of competitors. Individual evaluations must be objective and oriented to evaluation of performances of services.

Management must suppress subjective impressions, subjective entitlements, subjective promotion choices, like in science. Management must not entitle unproven people with critical decision roles. Organizations need to implement credit incentives to development of new generations of leaders.

Ethical impacts are credit and information flows may be more important than individual life or freedom of speech. Another fact is that any person may bring durable change as it is enough knowing what and how to do. The natural selection between institutions has the tendency to end unfair credit and privileges.

In steady state, constructal law of institutions predicts a single country tend to achieve global economic unification, orienting every economy in the world toward it. Political unification, within a totalitarian state, may also be a fateful destiny because the most improved flow system tends to destroy its competitors.

Further work could be more checks on history of societies (or firms) ascension and fall using quantified data. Of course, an index may quantify how much a society protected information and credit flows adding points to each institution with this finality. The received taxes (or firm earnings) may give a measure of realization. With both data, it may be possible to check the correlation between flows and realization. Another field of research could be the time response of human societies given an institutional change or set of reforms.

\section{References}

[1] Dalton, D.R., Hitt, M.A., Certo, S.T. and Dalton, C.M. (2007) The Fundamental Agency Problem and Its Mitigation. The Academy of Management Annals, 1, 1-64. https://doi.org/10.1080/078559806

[2] Marquis, C., Glynn, M.A. and Davis, G.F. (2007) Community Isomorphism and Corporate Social Action. Academy of Management Review, 32, 925-945. https://doi.org/10.5465/AMR.2007.25275683

[3] Dimaggio, P.J. (1988) Interest and Agency in Institutional Theory. 
[4] Battilana, J., Leca, B. and Eva, B. (2009) How Actors Change Institutions: Towards a Theory of Institutional Entrepreneurship. The Academy of Management Annals, 3, 65-107. https://doi.org/10.1080/19416520903053598

[5] Aldrich, H.E. and Fiol, C.M. (1994) Fools Rush in? The Institutional Context of Industry Creation. The Academy of Management Review, 19, 645-670.

[6] Pfeffer, J. and Salancik, G.R. (1978) The External Control of Organizations: A Resource Dependence Perspective. Harper \& Row, New York.

[7] Hillman, A.J., Withers, M.C. and Collins, B.J. (2009) Resource Dependence Theory: A Review. Journal of Management, 35, 1404-1427. https://doi.org/10.1177/0149206309343469

[8] Bejan, A. and Lorente, S. (2013) Constructal Law of Design and Evolution: Physics, Biology, Technology, and Society. Journal of Applied Physics, 113, Article ID: 151301. https://doi.org/10.1063/1.4798429

[9] Bejan, A. and Lorente, S. (2011) The Constructal Law Origin of the Logistics S Curve. Journal of Applied Physics, 110, Article ID: 024901.

https://doi.org/10.1063/1.3606555

[10] Bejan, A. and Merkx, G.W. (2007) Constructal Theory of Social Dynamics. Springer, Berlin.

[11] Odebrecht, N. (2011) Survival, Growth and Perpetuity. 11th Edition.

[12] Seeley, T.D. (1996) The Wisdom of the Hive-The Social Physiology of Honey Bee Colonies. Harvard University Press, Cambridge.

[13] Leoncini, I., Le Conte, Y., Costagliola, G., Plettner, E., Toth, A.L., Wang, M., Huang, Z., Bécard, J.-M., Crauser, D., Slessor, K.N. and Robinson, G.E. (2004) Regulation of Behavioral Maturation by a Primer Pheromone Produced by Adult Worker Honey Bees. Proceedings of the National Academy of Sciences of the United States of America, 101, 17559-17564. https://doi.org/10.1073/pnas.0407652101

[14] Riley, J.R., Greggers, U., Smith, A.D., Reynolds, D.R. and Menzel, R. (2005) The Flight Paths of Honeybees Recruited by the Waggle Dance. Nature, 435, 205-207. https://doi.org/10.1038/nature03526

[15] Seeley, T.D. (2010) Honeybee Democracy. Princeton University Press, Princeton.

[16] Gould, J. (1983) Biology. Science News, 123, 271-276.

[17] Butler, C.G. (1957) The Process of Queen Supersedure in Colonies of Honeybees (Apis mellifera Linn.). Insectes Sociaux, 4, 211-223.

[18] Rathbone, D. (2009) Earnings and Costs: Living Standards and the Roman Economy. In: Wilson, A., Ed., Quantifying the Roman Economy Methods and Problems, Oxford University Press, Oxford, 299-326. https://doi.org/10.1093/acprof:oso/9780199562596.003.0015

[19] Drinkwater, J. (1999) León J. C. S.: Los Bagaudas: Rebeldes, demonios, mártires. RevueltascampesinasenGalia e Hispania durante el BajoImperio. Pp. 168.Jaén: Universidad de Jaén, 1996. Paper. ISBN: 84-88942-49-4. The Classical Review, 49, 287-288. https://doi.org/10.1093/cr/49.1.287

[20] Harari, Y.N. (2014) Sapiens: A Brief History of Humankind. Harper, New York.

[21] Duyvendak, J.J.-L. (1928) The Book of Lord Shang. Londres, London. 